\title{
Underweight and overweight/obesity among adults in Afghanistan: Prevalence and correlates from a national survey in 2018
}

\section{Supa Pengpid}

Mahidol University AIHD: Mahidol University ASEAN Institute for Health Development

Karl Peltzer ( $\nabla$ kfpeltzer@gmail.com )

University of the Free State - Bloemfontein Campus: University of the Free State https://orcid.org/0000-0002-59800876

\section{Research article}

Keywords: body weight, health behaviour, health status, adulthood

Posted Date: April 8th, 2021

DOI: https://doi.org/10.21203/rs.3.rs-366120/v1

License: (c) (1) This work is licensed under a Creative Commons Attribution 4.0 International License. Read Full License 


\section{Abstract \\ Background}

The study aimed to estimate the prevalence and correlates of underweight and overweight/obesity among adults in Afghanistan.

\section{Methods}

National cross-sectional survey data of 3,779 persons aged 18-69 years were analysed. Multinomial logistic regression was used to estimate factors associated with underweight and overweight/obesity relative to normal weight.

\section{Results}

In all, $7.8 \%$ of the study sample was underweight $\left(\mathrm{BMI}<18.5 \mathrm{~kg} / \mathrm{m}^{2}\right), 49.5 \%$ had normal weight $\left(\mathrm{BMI} 18.5-24.9 \mathrm{~kg} / \mathrm{m}^{2}\right)$, $25.5 \%$ overweight $\left(25.0-29.9 \mathrm{~kg} / \mathrm{m}^{2}\right)$, and $17.2 \%$ obesity. In adjusted multinomial logistic regression, factors negatively associated with underweight were male sex (Adjusted Relative Risk Ratio-ARRR: 0.55, Confidence Interval-Cl: 0.320.95). Factors positively associated with overweight/obesity were aged 30-44 years (ARRR: 1.92, Cl: 1.46-2.53) and aged 45-69 years (ARRR: 1.49, Cl: 1.05-2.11) (compared to 18-29 years) (ARRR: 1.28, Cl: 1.14-2.18), hypertension (ARRR: 2.69, Cl: 1.88-3.85), type 2 diabetes (ARRR: 1.81, Cl: 1.15-2.86), and raised cholesterol (ARRR: 2.04, Cl: 1.412.95).

\section{Conclusion}

Almost one in ten adult respondents were underweight and more than two in five were overweight/obese, confirming a dual burden of malnutrition in Afghanistan.

\section{Introduction}

Worldwide, among adults, the prevalence of undernutrition $\left(18.5<\mathrm{kg} / \mathrm{m}^{2}\right)$ was $8.8 \%$ among men and $9.7 \%$ among women, and the prevalence of obesity $\left(\mathrm{BMI} \geq 30 \mathrm{~kg} / \mathrm{m}^{2}\right)$ was $10.8 \%$ among men and $14.9 \%$ among women [1]. In the Eastern Mediterranean region, a high average prevalence of overweight/obesity (51\%) has been reported [2]. In local community surveys in urban centres in Afghanistan, the following proportions of body weight status have previously been shown: in Kabul City ( $\geq 40$ years, in 2011-2012), underweight 1.1\% and overweight/obesity 69.3\% [3], in Kabul (25-70 years, in 2015), 57.6\% overweight/obesity [4], in Jalalabad (25-65 years, in 2013) underweight 6.1\% [5] and overweight/obesity 57.4\% [6], and in Kabul, Balkh, Hirat, Nangarhar and Kandahar (25-70 years, during 2013-2015) overweight/obesity was 52.7\% [7]. In a national study among women 15-49 years in Afghanistan, the prevalence of underweight was $8.6 \%$ [8]. To our knowledge, there are no national adult body weight status data in Afghanistan.

In the Eastern Meditarranean region, the prevalence of overweight/obesity among adults ranged from 25-81.9\% [9]. In Iran, the prevalence of underweight was $5.9 \%$ and $49.9 \%$ had overweight/obesity (15-65 years, in 2004-2005) [10], in Iraq ( $\geq 15$ years, in 2015) underweight 3.6\% and overweight/obesity 65.7\% [11], in Jordan overweight or obesity (BMI $\geq 25 \mathrm{~kg} / \mathrm{m}^{2}$ ) was $77.2 \%$ among men and 74.5\% among women ( $\geq 18$ years; 2017) [12], in Morocco underweight was 
$5.6 \%$ and overweight/obesity $56.1 \%$ ( $\geq 18$ years; 2017 ) [13], and in Palestine (18-64 years, 1999-2000) underweight was $1.5 \%$ and overweight/obesity $62.4 \%[14]$.

Both undernutrition and overnutrition in adulthood have been linked to various negative health effects, including morbidity and mortality $[15,16]$. As reviewed [17], sociodemographic factors associated with adult underweight may include female sex, younger and older age, lower socioeconomic status, and residing in rural areas. Health variables associated with adult underweightmay include poor diets, smoking, and not having chronic conditions. As reviewed [17] sociodemographic factors associated with overweight/obesity include female sex, increasing age, higher socioeconomic status, and urban residence, and health variables associated with overweight/obesity may include, poor diet, physical inactivity, not smoking, diabetes, dyslipidaemia and hypertension. Afghanistan has a high prevalence of undernutrition in children (19.1\% in 2018) under the age of five [8, 18], which may affect adult weight status. Afghanistan is a low income country, its living standards are among the lowest in the world, has a population of 36.6 million, life expectance at birth was 52.8 years, and an adult literacy rate of $43 \%$ (55.5\% among men and $29.8 \%$ among women [18]. The study aimed to estimate for the first time the national prevalence and correlates of underweight and overweight/among adults in Afghanistan.

\section{Methods}

This is a secondary analysis conducted using nationally representative population-based and cross-sectional data from the "2018 Afghanistan STEPS survey" [19]. The 2018 Afghanistan STEPS survey data and more detailed sampling methods can be accessed [20]. Briefly, a multistage cluster sampling was used to generate a nationally representative sample of adults aged 18-69 years. Stage 1 or primary sampling units were 55 districts, followed by villages or blocks (secondary sampling units), and households (tertiary sampling units). One person from each household was randomly selected [20]. In total, 3,956 persons aged 18-69 years were potentially eligible in this study. However, 177 women were excluded as they had indicated to be pregnant during the study so that 3,779 participants were included in the final data analysis. The study instrument was translated to Pashto and Dari and piloted [20]. The study was approved by the Ministry of Public Health Ethics Board, and written informed consent was obtained from participants [20].

\section{Measures}

Anthropometric measurements were taken by trained healthcare staff in a safe and secure area; height and weight were measured using a portable electronic weighing scale and measuring inflexible bars [20]. Body Mass Index (BMI) was classified as " $<18.5 \mathrm{~kg} / \mathrm{m}^{2}$ underweight, $18.5-24.4 \mathrm{~kg} / \mathrm{m}^{2}$ normal weight, $25-29.9 \mathrm{~kg} / \mathrm{m}^{2}$ overweight and $\geq 30 \mathrm{~kg} / \mathrm{m}^{2}$ obesity" [21].

Hypertension or raised blood pressure (BP) was defined as "systolic BP $\geq 140 \mathrm{~mm} \mathrm{Hg}$ and/or diastolic BP $\geq 90 \mathrm{~mm} \mathrm{Hg}$ or where the participant is currently on antihypertensive medication." [22]. BP was measured with a calibrated sphygmomanometer after participants had been seated at least for 15 minutes, and three minutes in between readings. Of the three BP measurements, the last two readings were averaged [20].

Diabetes was defined as "fasting plasma glucose levels $>=7.0 \mathrm{mmol} / \mathrm{L}(126 \mathrm{mg} / \mathrm{dl})$; or using insulin or oral hypoglycaemic drugs; or having a history of diagnosis of diabetes" [23].

History of cardiovascular disorder was asked with questions on having had a heart attack and stroke (Yes, No) [20]. 
Health risk behaviourvariables comprised alcohol use, exposure to secondary smoke, smoking status, dietary behaviour (fruit and vegetable servings/day and number of meals outside home in the past week), and sedentary behaviour ( $\geq 8$ hours/day [24]), and "low, moderate or high physical activity based on the Global Physical Activity Questionnaire" [25].

Sociodemographic information included age, sex, highest educational level, number of adult household members, and residence status [20]. Household crowding has been found to have an inverse relationship with socioeconomic status [26].

\section{Data analysis}

All statistical procedures were adjusted for complex sample design and conducted with "STATA software version 13.0 (Stata Corporation, College Station, TX, USA)". The data were weighted "to make the sample representative of the target population in Afghanistan (by sex and by age group: 18-29, 30-44, 45 and over)." [20]. Chi-square test calculated differences in proportions. Multivariable multinomial logistic regression was used to estimate predictors of underweight and overweight/obesity (with normal body weight forming the reference category). Variables significant at $p<0.1$ were included in the final model. No multi-collinearity was detected. Missing data were excluded from the analysis. $P<0.05$ was considered significant.

\section{Results}

\section{Sample and body mass index information}

The sample consisted 3,779 individuals aged 18-69 years (median age: 35 years, 24-48 interquartile range), and $55.9 \%$ were male. Almost half of the participants (47.2\%) were living with five or more adult household members, $59.0 \%$ had no formal education, and $42.4 \%$ lived in rural areas. In all, $7.8 \%$ of the study sample was underweight (BMI < $\left.18.5 \mathrm{~kg} / \mathrm{m}^{2}\right), 49.5 \%$ had normal weight (BMI 18.5-24.9 kg/m²), 25.5\% overweight $\left(25.0-29.9 \mathrm{~kg} / \mathrm{m}^{2}\right)$, and $17.2 \%$ obesity. Further sample details are shown in Table 1 (see Table 1). 
Table 1

Sample and nutritional status among adults in Afghanistan, 2018

\begin{tabular}{|c|c|c|c|c|c|c|}
\hline Variable (\#missing values) & Sample & $\begin{array}{l}\text { Normal } \\
\text { weight }\end{array}$ & Underweight & Overweight & Obesity & $\begin{array}{l}\text { p- } \\
\text { value }\end{array}$ \\
\hline & $\mathrm{N}(\%)$ & $\mathrm{N}(\%)$ & $\mathrm{N}(\%)$ & $\mathrm{N}(\%)$ & $\mathrm{N}(\%)$ & \\
\hline All & 3779 & $1774(49.5)$ & $264(7.8)$ & $\begin{array}{l}1071 \\
(25.5)\end{array}$ & $\begin{array}{l}636 \\
(17.2)\end{array}$ & \\
\hline Age in years $(\# 30)$ & $\begin{array}{l}1382 \\
(441)\end{array}$ & $776(58.8)$ & $131(8.9)$ & $307(21.0)$ & $\begin{array}{l}144 \\
(11.3)\end{array}$ & $<001$ \\
\hline $18-29$ & & $460(42.7)$ & $69(7.4)$ & 352 (27.1) & & \\
\hline $30-44$ & $(32.2)$ & $525(41.8)$ & $62(6.2)$ & $402(31.6)$ & $\begin{array}{l}239 \\
(22.8)\end{array}$ & \\
\hline $45-69$ & $\begin{array}{l}1243 \\
(23.8)\end{array}$ & & & & $\begin{array}{l}252 \\
(20.4)\end{array}$ & \\
\hline $\operatorname{Sex}(\# 4)$ & 1753 & $723(42.1)$ & $156(9.1)$ & $465(25.1)$ & 389 & $<$ \\
\hline Female & & $1051(55.3)$ & $108(6.7)$ & $606(25.9)$ & & \\
\hline Male & $(55.9)$ & & & & $(12.1)$ & \\
\hline Education (\#3) & $\begin{array}{l}2094 \\
(59.0)\end{array}$ & 940 (46.9) & $147(6.4)$ & $582(26.8)$ & 411 & 0.133 \\
\hline & & & $38(8.5)$ & $206(23.1)$ & & \\
\hline & (16.4) & & 79 (10.7) & $283(24.0)$ & (15.4) & \\
\hline Primary or less & $\begin{array}{l}1023 \\
(24.6)\end{array}$ & $525(53.4)$ & & & $\begin{array}{l}122 \\
(11.9)\end{array}$ & \\
\hline Secondary or more & & & & & & \\
\hline Adult household members (\#3) & $\begin{array}{l}1992 \\
(528)\end{array}$ & 941 (49.5) & $145(7.8)$ & $583(29.2)$ & 302 & 0.094 \\
\hline$<5$ & & $833(49.5)$ & 119 (7.7) & $488(23.1)$ & & \\
\hline$\geq 5$ & $(47.2)$ & & & & $(19.7)$ & \\
\hline Residence (\#1) & & & & & & \\
\hline Rural & 1797 & $922(51.9)$ & $140(8.3)$ & $471(25.1)$ & 249 & 0.306 \\
\hline Urban & & 852 (47.7) & $124(7.3)$ & $600(25.8)$ & & \\
\hline & $\begin{array}{l}1981 \\
(57.6)\end{array}$ & & & & $\begin{array}{l}387 \\
(19.1)\end{array}$ & \\
\hline $\begin{array}{l}\text { Fruit and vegetable consumption } \\
(\# 0)\end{array}$ & & & & & & \\
\hline$\leq 1$ servings & 2415 & $1164(50.3)$ & $182(8.7)$ & $650(25.3)$ & $\begin{array}{l}401 \\
(157)\end{array}$ & 0.394 \\
\hline 2 servings & & $389(47.9)$ & $51(6.8)$ & $285(27.8)$ & & \\
\hline$\geq 3$ servings & (29.6) & $221(49.4)$ & $31(5.5)$ & $136(20.9)$ & $(17.5)$ & \\
\hline & $\begin{array}{l}481 \\
(11.4)\end{array}$ & & & & $\begin{array}{l}86 \\
(24.2)\end{array}$ & \\
\hline
\end{tabular}




\begin{tabular}{|c|c|c|c|c|c|c|}
\hline Variable (\#missing values) & Sample & $\begin{array}{l}\text { Normal } \\
\text { weight }\end{array}$ & Underweight & Overweight & Obesity & $\begin{array}{l}\mathrm{p}- \\
\text { value }\end{array}$ \\
\hline $\begin{array}{l}\text { Meals outside home }(\# 55) \\
0 \\
\geq 1\end{array}$ & $\begin{array}{l}2477 \\
(65.9) \\
1247 \\
(34.1)\end{array}$ & $\begin{array}{l}1133(47.0) \\
610(53.9)\end{array}$ & $\begin{array}{l}178(8.3) \\
79(6.5)\end{array}$ & $\begin{array}{l}684(25.7) \\
376(25.4)\end{array}$ & $\begin{array}{l}468 \\
(19.0) \\
376 \\
(14.1)\end{array}$ & 0.374 \\
\hline Physical activity (\#35) & & & & & & \\
\hline $\begin{array}{l}\text { Low } \\
\text { Moderate } \\
\text { High }\end{array}$ & $\begin{array}{l}1384 \\
(38.4) \\
624 \\
(18.3) \\
1736 \\
(43.3)\end{array}$ & $\begin{array}{l}591(41.5) \\
267(50.9)\end{array}$ & $\begin{array}{l}94(7.6) \\
46(7.3)\end{array}$ & $\begin{array}{l}377(27.1) \\
202(24.4)\end{array}$ & $\begin{array}{l}303 \\
(23.8) \\
106 \\
(17.4) \\
221 \\
(11.4)\end{array}$ & $\begin{array}{l}< \\
0.001\end{array}$ \\
\hline Sedentary behaviour (\#24) & & & & & & \\
\hline $\begin{array}{l}<8 \text { hours/day } \\
\geq 8 \text { hours/day }\end{array}$ & $\begin{array}{l}2128 \\
(51.9) \\
1627 \\
(48.1)\end{array}$ & $\begin{array}{l}1037(54.5) \\
725(44.1)\end{array}$ & $\begin{array}{l}144(6.6) \\
120(9.1)\end{array}$ & $\begin{array}{l}580(23.9) \\
486(27.1)\end{array}$ & $\begin{array}{l}346 \\
(15.1) \\
286 \\
(19.6)\end{array}$ & 0.012 \\
\hline Current tobacco use (\#3) & & & & & & \\
\hline $\begin{array}{l}\text { No } \\
\text { Yes }\end{array}$ & $\begin{array}{l}2910 \\
(72.0) \\
866 \\
(28.0)\end{array}$ & $\begin{array}{l}1348(50.2) \\
426(47.7)\end{array}$ & $\begin{array}{l}207(7.0) \\
57(9.6)\end{array}$ & $\begin{array}{l}825(25.0) \\
246(26.9)\end{array}$ & $\begin{array}{l}502 \\
(17.8) \\
134 \\
(15.8)\end{array}$ & 0.557 \\
\hline Ever alcohol use (\#3) & & & & & & \\
\hline $\begin{array}{l}\text { No } \\
\text { Yes }\end{array}$ & $\begin{array}{l}3732 \\
(99.5) \\
44(0.5)\end{array}$ & $\begin{array}{l}1751(49.4) \\
23(58.9)\end{array}$ & $\begin{array}{l}261(7.8) \\
3(8.4)\end{array}$ & $\begin{array}{l}1059 \\
(25.5) \\
12(21.5)\end{array}$ & $\begin{array}{l}630 \\
(17.3) \\
6(11.2)\end{array}$ & 0.835 \\
\hline Hypertension (\#40) & & & & & & \\
\hline $\begin{array}{l}\text { No } \\
\text { Yes }\end{array}$ & $\begin{array}{l}2566 \\
(69.3) \\
1173 \\
(30.7)\end{array}$ & $\begin{array}{l}1376(56.9) \\
391(32.6)\end{array}$ & $\begin{array}{l}218(9.8) \\
46(3.1)\end{array}$ & $\begin{array}{l}667(21.9) \\
404(33.8)\end{array}$ & $\begin{array}{l}304 \\
(11.4) \\
331 \\
(30.4)\end{array}$ & $<0.001$ \\
\hline Type 2 diabetes (\#292) & & & & & & \\
\hline $\begin{array}{l}\text { No } \\
\text { Yes }\end{array}$ & $\begin{array}{l}3083 \\
(90.3) \\
404(9.7)\end{array}$ & $1500(52.2)$ & $211(7.7)$ & $870(25.1)$ & $\begin{array}{l}480 \\
(14.9) \\
98 \\
(36.6)\end{array}$ & $<.001$ \\
\hline $\begin{array}{l}\text { Raised cholesterol (\#231) } \\
\text { No } \\
\text { Yes }\end{array}$ & $\begin{array}{l}2902 \\
(83.3) \\
646 \\
(16.7)\end{array}$ & $\begin{array}{l}1445(53.6) \\
228(31.6)\end{array}$ & $221(7.9)$ & $\begin{array}{l}791(23.5) \\
227(36.6)\end{array}$ & $\begin{array}{l}427 \\
(15.0) \\
162 \\
(26.2)\end{array}$ & $<.001$ \\
\hline
\end{tabular}




\begin{tabular}{|lllllll|}
\hline Variable (\#missing values) & Sample & $\begin{array}{l}\text { Normal } \\
\text { weight }\end{array}$ & Underweight & Overweight & Obesity & $\begin{array}{l}\text { p- } \\
\text { value }\end{array}$ \\
\hline No & 3488 & $1658(49.6)$ & $250(7.9)$ & $978(25.5)$ & 571 & 0.933 \\
Yes & $(90.6)$ & $116(48.8)$ & $14(6.5)$ & $93(25.9)$ & $(17.1)$ & \\
& $288(9.4)$ & & & & \multicolumn{2}{l}{\begin{tabular}{l}
$(18.7)$ \\
\hline
\end{tabular}} \\
\hline
\end{tabular}

\section{Multinomial logistic regression for underweight and overweight/obesity}

In adjusted multinomial logistic regression, factors negatively associated with underweight were male sex (Adjusted Relative Risk Ratio-ARRR: 0.55, Confidence Interval-Cl: 0.32-0.95). Factors positively associated with overweight/obesity were aged 30-44 years (ARRR: 1.92, Cl: 1.46-2.53) and aged 45-69 years (ARRR: 1.49, Cl: 1.052.11) (compared to 18-29 years) (ARRR: 1.28, Cl: 1.14-2.18), hypertension (ARRR: 2.69, Cl: 1.88-3.85), type 2 diabetes (ARRR: 1.81, Cl: 1.15-2.86), and raised cholesterol (ARRR: 2.04, Cl: 1.41-2.95) (see Table 2). 
Table 2

Multivariable associations with underweight and overweight/obesity (with normal weight as reference category)

\begin{tabular}{|c|c|c|c|c|}
\hline Variable & Underweight & & Overweight/Obesity & \\
\hline & Adjusted RRR (95\% Cl) & $p$-value & Adjusted RRR (95\% Cl) & $p$-value \\
\hline Age in years (\#10) & 1 (Reference) & 0.767 & 1 (Reference) & $<0.001$ \\
\hline $18-29$ & $1.09(0.60,1.98)$ & 0.938 & $1.92(1.46,2.53)$ & 0.024 \\
\hline $30-44$ & $1.03(0.54,1.93)$ & & $1.49(1.05,2.11)$ & \\
\hline \multicolumn{5}{|l|}{$45-69$} \\
\hline Sex $(\# 0)$ & 1 (Reference) & 0.032 & 1 (Reference) & 0.249 \\
\hline Female & $0.55(0.32,0.95)$ & & $0.80(0.55,1.17)$ & \\
\hline \multicolumn{5}{|l|}{ Male } \\
\hline Adult household members (\#5) & 1 (Reference) & 0.901 & 1 (Reference) & 0.692 \\
\hline$<5$ & $0.96(0.47,1.94)$ & & $0.95(0.74,1.22)$ & \\
\hline \multicolumn{5}{|l|}{$\geq 5$} \\
\hline \multicolumn{5}{|l|}{ Physical activity (\#3) } \\
\hline Low & 1 (Reference) & 0.835 & 1 (Reference) & 0.196 \\
\hline Moderate & $1.09(0.47,2.55)$ & 0.867 & $0.77(0.52,1.14)$ & 0.054 \\
\hline High & $1.04(0.64,1.69)$ & & $0.72(0.51,1.01)$ & \\
\hline \multicolumn{5}{|l|}{ Sedentary behaviour (\#42) } \\
\hline$<8$ hours/day & 1 (Reference) & 0.092 & 1 (Reference) & 0.072 \\
\hline$\geq 8$ hours/day & $1.27(0.98,3.41)$ & & $1.27(0.55,1.17)$ & \\
\hline \multicolumn{5}{|l|}{ Hypertension (\#27) } \\
\hline No & 1 (Reference) & 0.065 & 1 (Reference) & $<0.001$ \\
\hline Yes & $0.53(0.27,1.04)$ & & $2.69(1.88,3.85)$ & \\
\hline \multicolumn{5}{|l|}{ Type 2 diabetes (\#204) } \\
\hline No & 1 (Reference) & 0.767 & 1 (Reference) & 0.011 \\
\hline Yes & $1.12(0.54,2.33)$ & & $1.81(1.15,2.86)$ & \\
\hline Raised cholesterol & 1 (Reference) & 0.692 & 1 (Reference) & $<0.001$ \\
\hline No & $1.20(0.49,2.95)$ & & $2.04(1.41,2.95)$ & \\
\hline \multicolumn{5}{|l|}{ Yes } \\
\hline RRR = Relative Risk Ratio; $\mathrm{Cl}=\mathrm{C}$ & fidence Interval & & & \\
\hline
\end{tabular}




\section{Discussion}

In this national 2018 Afghanistan STEPS survey, the prevalence of underweight (7.8\%) was higher than in Kabul City ( $\geq 40$ years, in 2011-2012) (1.1\%) [3], in Jalalabad (25-65 years, in 2013) (6.1\%) [5], in Iran 15-65 years, in 20042005) (5.9\%) [10], in Iraq ( $\geq 15$ years, in 2015) (3.6\%) [11], in Morocco ( $\geq 18$ years; 2017) (5.6\%) [13], and Palestine $(1.5 \%, 18-64$ years, $1999-2000)$ [14], but similar to a national study among women (15-49 years, $8.6 \%$ vs $9.1 \%$ in this study) in Afghanistan [8], and the global prevalence of underweight (8.8\% among men and 9.7\% among women) [1]. The found prevalence of overweight/obesity $\left(42.7 \%, \geq 25.0 \mathrm{~kg} / \mathrm{m}^{2}\right)$ in this study is lower than the prevalence rates found in urban centres in Afghanistan, e.g., in Kabul City (69.3\%, $\geq 40$ years, in 2011-2012) [3], in Kabul (57.6\%, 25-70 years, in 2015) [4], in Jalalabad (57.4\%, 25-65 years, in 2013) (57.4\%) [6], and in Kabul, Balkh, Hirat, Nangarhar and Kandahar $(52.7 \%, 25-70$ years, during $2013-2015)$ [7], in Iran $(59.3 \%, 2016)$ [27], in Iraq $(65.7 \%, \geq 15$ years, in 2015$)$ [11], in Morocco (56.1\% $\geq 18$ years; 2017) [13], Palestine (62.4\%, 18-64 years, 1999-2000) [14], and in Jordan (> 75\%, $\geq 18$ years; 2017) [12], but higher than global estimates ( $10.8 \%$ of men and $14.9 \%$ of women obesity) [1].

Findings show the double burden of undernutrition (7.8\%) and overnutrition $\left(42.7 \%, \geq 25 \mathrm{~kg} / \mathrm{m}^{2}\right)$ in the low-income country, Afghanistan. The co-existence of undernutrition (15.6\%) and overnutrition (18.0\%) has also been found in lowincome countries in the Asia Pacific region [28]. The trend in the reduction of underweight and increase of overweight/obesity $[1,28]$ seems to be confirmed in this study in Afghanistan. "Rapid dietary and lifestyle transition it is the leading direction of dual burden toward overnutrition increase and diet-related NCDs" $[28,29]$. In addition, it is possible that the high prevalence of undernutrition in children under the age of five in Afghanistan [8] has led to increased overnutrition in adulthood [30]. Increased efforts on policy initiatives and lifestyle changes are needed in Afghanistan to combat the double malnutrition burden.

The the prevalence of underweight was the highest among 18 to 29 year-olds (8.9\%) and among women (9.1\%), which was also found in previous studies [31-33], and may be attributed to food insecurity, in particular among young women [8,34]. Akseer et al. [8] showed that younger adolescent mothers ( $<20$ years) are more underweight than older mothers (20-49 years) in Afghanistan, attributing this to increased mother-child nutritional demands. Some previous research showed an association between lower socioeconomic status and underweight [17, 35, 36], but this study did not find this. One possible reason for this nonsignificant finding may be related to the measurement of economic status, which in this study was limited to the number of adult household members.

In bivariate analysis, obesity was higher in women (23.7\%) compared to men (12.1\%), which is in line with previous studies $[5,35,36]$. Consistent with previous research $[7,35,36]$, overweight/obesity increased with age. While some previous studies [5, 35-37], found an association between higher economic status (less household crowding), education, and residing in urban areas and having overweight/obesity, this survey did not show significant associations. Similar results of a non-association between education, income, and job categories with overweight/obesity in adults in Kabul [7]. It is possible that educational level did not impact on body weight status because of the high proportion of the study population (59.0\%) had no formal education. Of concern is as well that $32.3 \%$ of young people aged 18-29 years were already overweight or obese, showing that a large proportion of overweight/obesity is already established in early adulthood. Therefore, obesity interventions starting in childhood or adolescents should be prioritized in Afghanistan [38].

This study did not find an association between dietary behaviour (inadequate fruit and vegetable intake and having meals outside home) and underweight as well as overweight or obesity, unlike some previous research [17, 39, 40]. This study lacked to assess other dietary behaviours, such as frequent snaking, skipping breakfast, eating high amounts of processed or fast food, and high intake of sugary beverages, which may have been responsible for a higher rate of overweight/obesity $[9,41]$. 
In agreement with previous studies [37-39, 42,43], this study showed in bivariate analysis that physical activity was inversely and high sedentary behaviour was positively associated with overweight/obesity. Unlike some previous research $[5,38,42]]$, this study showed no (negative) association between current tobacco use and the prevalence of overweight/obesity. As shown previously [5-7, 38, 44, 45], we found an association between NCDs (hypertension, diabetes, and raised cholesterol) and overweight/obesity. This result emphasizes the fact that adults in Afghanistan suffer from several NCD risk factors at the same time [6], calling for multiple risk factor interventions [5, 7]. Implementing preventive interventions, such as programmes improving a healthy diet, appropriate food policies, promotion of physical activity and interrupting sedentary behaviour, and community awareness campaigns may help in ameliorating the high burden of overweight and obesity. The evaluation of experimental weight reduction interventions is recommended as future research to fine-tune intervention strategies in Afghanistan.

\section{Study Limitations}

Apart from physical and biomedical measures self-reported questionnaire data may have suffered from biased responses. Another limitation was the cross-sectional nature of the survey, which does not allow for causative conclusions. Some variables, such as more details on dietary behaviour, should be included in future studies.

\section{Conclusion}

The study found in the 2018 adult national Afghanistan STEPS survey that almost one in ten adult participants were underweight and more than two in five were overweight/obese. Several risk factors, including female sex for underweight and older age, hypertension type 2 diabetes, and raised cholesterol for overweight/obesity were identified, which can be targeted in interventions.

\section{Declarations}

All methods were carried out in accordance with relevant guidelines and regulations.

\section{Ethics approval and consent to participate}

The study was approved by the Ministry of Public Health Ethics Board, and written informed consent was obtained from participants [20].

\section{Consent for publication}

Not applicable

\section{Availability of data and materials}

"The data for the current study are publicly available at the World Health Organization NCD Microdata Repository (URL: https://extranet.who.int/ncdsmicrodata/index.php/catalog)."

\section{Competing interests}

The authors declare that they have no competing interests.

\section{Funding}

The analysis received no funding 


\section{Authors' contributions}

"All authors fulfil the criteria for authorship. SP and KP conceived and designed the research, performed statistical analysis, drafted the manuscript, and made critical revisions of the manuscript for key intellectual content. All authors read and approved the final version of the manuscript and have agreed to the authorship and order of authorship for this manuscript."

\section{Acknowledgements}

"The data source, the World Health Organization NCD Microdata Repository (URL: https://extranet.who.int/ncdsmicrodata/index.php/catalog), is hereby acknowledged."

\section{References}

1. NCD Risk Factor Collaboration (NCD-RisC). Trends in adult body-mass index in 200 countries from 1975 to 2014 : a pooled analysis of 1698 population-based measurement studies with 19.2 million participants. Lancet 2016;387(10026):1377-1396. doi: 10.1016/S0140-6736(16)30054-X.

2. Nasreddine L, Ayoub JJ, Al Jawaldeh A. Review of the nutrition situation in the Eastern Mediterranean Region. East Mediterr Health J. 2018 Apr 5;24(1):77-91. PMID: 29658624.

3. Saeed KMI. Prevalence of Risk Factors for Non-Communicable Diseases in the Adult Population of Urban Areas in Kabul City, Afghanistan. Cent Asian J Glob Health. 2014 Jan 3;2(2):69. doi: 10.5195/cajgh.2013.69.

4. Saeed KM. Burden of Hypertension in the Capital of Afghanistan: A Cross-Sectional Study in Kabul City, 2015. Int J Hypertens. 2017;2017:3483872. doi: 10.1155/2017/3483872.

5. SaeedKM (2015)Prevalence and associated risk factors for obesity in Jalalabad city - Afghanistan, Alexandria Journal of Medicine, 51:4, 347-352, DOI: 10.1016/j.ajme.2014.12.004

6. Saeed KM, Rasooly MH, Alkozai A. Prevalence of risk factors for noncommunicable diseases in Jalalabad city, Afghanistan, evaluated using the WHO STEPwise approach. East Mediterr Health J. 2016 Feb 1;21(11):783-90. PMID: 26857715.

7. Saeed KMI, Rasooly MH, Nejaby M. Profile of risk factors for noncommunicable diseases in major cities of Afghanistan: WHO STEPwise approach. East Mediterr Health J. 2020 Apr 16;26(4):388-399. doi: 10.26719/emhj.20.005. PMID: 32338357.

8. Akseer, N., Bhatti, Z., Mashal, T., Soofi, S., Moineddin, R., Black, R. E., \& Bhutta, Z. A. (2018). Geospatial inequalities and determinants of nutritional status among women and children in Afghanistan: an observational study. The Lancet. Global health, 6(4), e447-e459. https://doi.org/10.1016/S2214-109X(18)30025-1

9. Musaiger AO. Overweight and obesity in eastern mediterranean region: prevalence and possible causes. J Obes. 2011;2011:407237. doi: 10.1155/2011/407237.

10. Janghorbani, M., Amini, M., Willett, W. C., Mehdi Gouya, M., Delavari, A., Alikhani, S., \& Mahdavi, A. (2007). First nationwide survey of prevalence of overweight, underweight, and abdominal obesity in Iranian adults. Obesity (Silver Spring, Md.), 15(11), 2797-2808. https://doi.org/10.1038/oby.2007.332

11. Pengpid, S.; Peltzer, K. Overweight and Obesity Among Adults in Iraq: Prevalence and Correlates From a National Survey in 2015. Preprints2020, 2020110489 (doi: 10.20944/preprints202011.0489.v1)

12. Ajlouni K, Khader Y, Batieha A, Jaddou H, El-Khateeb M. An alarmingly high and increasing prevalence of obesity in Jordan. Epidemiol Health. 2020;42:e2020040. doi: 10.4178/epih.e2020040. 
13. Pengpid S, Peltzer K. Prevalence and correlates of the metabolic syndrome in a cross-sectional community-based sample of 18-100 year-olds in Morocco: Results of the first national STEPS survey in 2017. Diabetes Metab Syndr. 2020 Sep-Oct;14(5):1487-1493. doi: 10.1016/j.dsx.2020.07.047.

14. Abdeen Z, Jildeh C, Dkeideek S, Qasrawi R, Ghannam I, Al Sabbah H. Overweight and Obesity among Palestinian Adults: Analyses of the Anthropometric Data from the First National Health and Nutrition Survey (1999-2000). J Obes. 2012;2012:213547. doi: 10.1155/2012/213547.

15. Nubé M, Van Den Boom GJ. Gender and adult undernutrition in developing countries. Ann Hum Biol. 2003;30(5): 520-537.

16. Pi-Sunyer X. The medical risks of obesity. Postgrad Med. 2009;121(6): 21-33.

17. Pengpid S, Peltzer K. The prevalence and associated factors of underweight and overweight/obesity among adults in Kenya: evidence from a national cross-sectional community survey. Pan Afr Med J. 2020 Aug 25;36:338. doi: 10.11604/pamj.2020.36.338.21215.

18. World Factbook. Afghanistan. URL: https://www.cia.gov/library/publications/the-world-factbook/geos/af.html (accessed 25 Nov 2020)

19. World Health Organization (WHO) (2018) STEPwise approach to surveillance (STEPS). URL: https://www.who.int/ncds/surveillance/steps/en/

20. JS Consultancy Services, Non-Communicable Disease Risk Factor Survey Country Report for Afghanistan. URL: https://extranet.who.int/ncdsmicrodata/index.php/catalog/782

21. World Health Organization (WHO)- Europe. Body Mass Index https://www.euro.who.int/en/health-topics/diseaseprevention/nutrition/a-healthy-lifestyle/body-mass-index-bmi (20 September 2020)

22. Chobanian, A.V.; Bakris, G.L.; Black, H.R.; Cushman, W.C.; Green, L.A.; Izzo, J.L.Jr.; Jones, D.W.; Materson, B.J.; Oparil, S.; Wright, J.T.; et al. Seventh report of the Joint National Committee of Prevention, Detection, Evaluation, and Treatment of High Blood Pressure. Hypertension. 2003, 42(6), 1206-52. http://dx.doi. org/10.1161/01.HYP.0000107251.49515.c2

23. NCD Risk Factor Collaboration (NCD-RisC). Worldwide trends in diabetes since 1980: a pooled analysis of 751 population-based studies with 4.4 million participants. Lancet 2016, 387(10027), 1513-30. http://dx.doi.org/10.1016/S0140-6736(16)00618-8

24. Ekelund, U.; Steene-Johannessen, J.; Brown, W.J.; Fagerland, M.W.; Owen, N.; Powell, K.E.; Bauman, A.; Lee, I.M.; Lancet Physical Activity Series 2 Executive Committee; Lancet Sedentary Behaviour Working Group. Does physical activity attenuate, or even eliminate, the detrimental association of sitting time with mortality? A harmonised metaanalysis of data from more than 1 million men and women. Lancet 2016, 388, 1302-1310.

25. Armstrong, T.; Bull, F. Development of theWorld Health Organization Global Physical Activity Questionnaire (GPAQ). J. Public Health 2006, 14, 66-70.

26. Melki IS, Beydoun HA, Khogali M, Tamim H, Yunis KA; National Collaborative Perinatal Neonatal Network (NCPNN). Household crowding index: a correlate of socioeconomic status and inter-pregnancy spacing in an urban setting. $J$ Epidemiol Community Health. 2004 Jun;58(6):476-80. doi: 10.1136/jech.2003.012690.

27. Djalalinia S, Saeedi Moghaddam S, Sheidaei A, Rezaei N, Naghibi Iravani SS, Modirian M, Zokaei H, Yoosefi M, Gohari K, Kousha A, Abdi Z, Naderimagham S, Soroush AR, Larijani B, Farzadfar F. Patterns of Obesity and Overweight in the Iranian Population: Findings of STEPs 2016. Front Endocrinol. 2020 Feb 26;11:42. doi: 10.3389/fendo.2020.00042.

28. Peng W, Mu Y, Hu Y, Li B, Raman J, Sui Z. Double Burden of Malnutrition in the Asia-Pacific Region-A Systematic Review and Meta-analysis. J Epidemiol Glob Health. 2020 Mar;10(1):16-27. doi: 10.2991/jegh.k.191117.002. 
29. Popkin BM. An overview on the nutrition transition and its health implications: the Bellagio meeting. Public Health Nutr 2002;5;93-103.

30. Haddad L, Cameron L, Barnett I. The double burden of malnutrition in SE Asia and the Pacific: priorities, policies and politics. Health Policy Plan 2015;30;1193-206.

31. Hanandita W, Tampubolon G (2015) The double burden of malnutrition in Indonesia: Social determinants and geographical variations. SMM- Population Health 1: 16-25. doi: 10.1016/j.ssmph.2015.10.002. eCollection 2015 Dec.

32. Letamo G, Navaneetham K (2014) Prevalence and determinants of adult under-nutrition in Botswana. PLoS One 9: e102675. doi: 10.1371/journal.pone.0102675. eCollection 2014.

33. Pengpid S, Vonglokham M, Kounnavong S, Sychareun V, Peltzer K. The prevalence of underweight and overweight/obesity and its correlates among adults in Laos: a cross-sectional national population-based survey, 2013. Eat Weight Disord. 2020 Apr;25(2):265-273. doi: 10.1007/s40519-018-0571-5.

34. Jaacks LM, Slining MM, Popkin BM (2015) Recent trends in the prevalence of under- and overweight among adolescent girls in low- and middle-income countries. Pediatr Obes 10(6):428-35. doi: 10.1111/ijpo.12000.

35. Biswas T, Garnett SP, Pervin S, Rawal LB. The prevalence of underweight, overweight and obesityin Bangladeshi adults: Data from a national survey. PLoS One 2017;12(5):e0177395. doi: 10.1371/journal.pone.0177395. eCollection 2017.

36. Pengpid S, Peltzer K. The prevalence of underweight, overweight and obesityand their related lifestyle factors in Indonesia, 2014-15. AIMS Public Health 2017;4(6): 633-649 DOI: 10.3934/publichealth.2017.6.633.

37. Mkuu RS, Epnere K, Chowdhury MAB. Prevalence and Predictors of Overweight and ObesityAmong Kenyan Women. Prev Chronic Dis.2018;15:E44. doi: 10.5888/pcd15.170401.

38. Weiderpass E, Botteri E, Longenecker JC, Alkandari A, Al-Wotayan R, Al Duwairi Q, Tuomilehto J. The Prevalence of Overweight and Obesity in an Adult Kuwaiti Population in 2014. Front Endocrinol. 2019 Jul 9;10:449. doi: 10.3389/fendo.2019.00449.

39. Pengpid S, Peltzer K. Associations between behavioural risk factors and overweight and obesityamong adults in population-based samples from 31 countries. Obes Res Clin Pract 2017;11(2):158-166. doi: 10.1016/j.orcp.2016.08.001

40. Carnauba RA, Chaves DF, Baptistella AB, Paschoal V ${ }^{1}$, Naves $A^{1}$, Buehler AM. Association between high consumption of phytochemical-rich foods and anthropometric measures: a systematic review. Int J Food Sci Nutr 2017; 68(2):158-166. doi: 10.1080/09637486.2016.1229761.

41. Al-Tawil NG, Abdulla MM, Abdul Ameer AJ. Prevalence of and factors associated with overweight and obesity among a group of Iraqi women. East Mediterr Health J. 2007 Mar-Apr;13(2):420-9.

42. Shabu, S. Prevalence of overweight/obesity and associated factors in adults in Erbil, Iraq: A household survey. Zanco J Med Sci. 2019;23(1):128-134. https://doi.org/10.15218/zjms.2019.017

43. World Health Organization (WHO). Obesity and overweight fact sheet, 2011. Department of Sustainable Development and Healthy Environments. URL:

http://www.searo.who.int/entity/noncommunicable_diseases/media/non_communicable_diseases_obesity_fs.pdf (accessed 10 June 2020).

44. Leggio M, Lombardi M, Caldarone E, Severi P, D'Emidio S, Armeni M, et al. The relationship between obesity and hypertension: an updated comprehensive overview on vicious twins. Hypertens Res 2017; 40(12):947-963. doi: 10.1038/hr.2017.75.

Page $13 / 14$ 
45. DiBonaventura MD, MeinckeH, Le Lay A, Fournier J, Bakker E, Ehrenreich A. Obesityin Mexico: prevalence, comorbidities, associations with patient outcomes, and treatment experiences. Diabetes Metab Syndr Obes 2017;11:1-10. doi: 10.2147/DMSO.S129247. eCollection 2018. 